\title{
Perbandingan Pemberian Informasi Verbal dengan Presentasi Video terhadap Pengetahuan Prosedur Anestesi Umum pada Pasien yang Akan Menjalani Operasi di RSUP Dr. Hasan Sadikin Bandung
}

\author{
Yodi Suryo Arnanto, ${ }^{1}$ Ruli Herman Sitanggang, ${ }^{2}$ Nurita Dian Kestriani Saragi Sitio ${ }^{2}$ \\ ${ }^{1}$ Instalasi Bedah RSUD Agats, Papua, ${ }^{2}$ Departemen Anestesiologi dan Terapi Intensif \\ Fakultas Kedokteran Universitas Padjadjaran/RSUP Dr. Hasan Sadikin Bandung
}

\begin{abstract}
Abstrak
Informasi mengenai indikasi, tujuan, prosedur, risiko, manfaat, dan alternatif tindakan anestesi yang akan dilakukan harus disampaikan kepada pasien. Pemberian informasi dilakukan secara verbal atau lisan pada saat proses persetujuan tindakan kedokteran. Kemampuan pasien yang berbeda-beda dalam menerima dan memahami informasi dapat menjadi penyebab tujuan penyampaian informasi tidak tercapai. Penelitian ini bertujuan membandingkan pemberian informasi verbal dengan presentasi video terhadap pengetahuan prosedur anestesi umum pada pasien yang akan menjalani operasi di RSUP Dr. Hasan Sadikin Bandung. Penelitian dilakukan pada 6 Februari-31 Maret 2018 dengan metode cross-sectional randomized study dan melibatkan 40 orang pasien yang akan menjalani operasi di RSUP Dr. Hasan Sadikin Bandung. Dilakukan penilaian pengetahuan subjek mengenai prosedur anestesi umum dengan menggunakan kuesioner. Data numerik dianalisis dengan uji t tidak berpasangan dan data kategorik dianalisis menggunakan uji chi-square. Penelitian ini memberikan hasil bahwa tidak terdapat perbedaan signifikan antara pemberian informasi dan metode verbal maupun presentasi video terhadap pengetahuan prosedur anestesi umum pada pasien $(p>0,05)$. Sebagai simpulan, penelitian ini menunjukkan bahwa presentasi video yang tidak dibuat sesuai dengan kaidah pembelajaran kognitif dan teori multimedia tidak memberikan pengetahuan yang lebih baik dibanding dengan metode verbal.
\end{abstract}

Kata kunci: Pengetahuan prosedur anestesi umum, pemberian informasi verbal, persetujuan tindakan kedokteran, presentasi video

\section{Comparison of Verbal and Video Presentation Method of Information Disclosure on Knowledge on General Anesthesia Procedure among Patients Undergoing Surgery in Dr. Hasan Sadikin General Hospital Bandung}

\begin{abstract}
Information on the indication, purpose, procedure, risks, benefits, and alternatives of any medical action should be disclosed to the patient. Patient should be given verbal information on any medical action he/she was about to undergo during the informed consent process. The variations in patient's ability to accept and understand information given to them could hinder the purpose of information disclosure during informed consent. The aim of this study was to assess the effect of video presentation on general anesthesia procedure on the knowledge of patients who were going to undergo surgery. This was a randomized cross-sectional study conducted from February 6-March 31, 2018 involving 40 patients who were about to undergo surgery in Dr Hasan Sadikin General Hospital. Afterwards, patient knowledge on the general anesthesia procedure was assessed. The numerical data were analyzed by unpaired $t$ test and categorical data were analyzed using Chi-Square analysis. This study showed that there was no significant difference between verbal and video presentation method of giving information on patient's knowledge regarding the general anesthesia procedure $(p>0.05)$. In conclusion, a video presentation which is designed without paying attention to the principles of cognitive learning and multimedia theories does not lead to better knowledge compared to the verbal method.
\end{abstract}

Key words: Informed consent, patient's knowledge about general anesthesia procedure, verbal disclosure, video presentation

Korespondensi: Yodi Suryo Arnanto, dr., SpAn, Instalasi Bedah RSUD Agats, Papua, Jl misi Kabupaten Asmat Provinsi Papua,Email yodibius@gmail.com 


\section{Pendahuluan}

Hukum menyatakan bahwa setiap individu yang termasukusia dewasa dianggap kompeten dan dapat mengambil keputusan mengenai rencana kesehatannya kecuali ditentukan sebaliknya oleh keputusan pengadilan. Kebebasan tersebut dilandasi oleh prinsip etika otonomi. Salah satu bentuk praktik dari prinsip otonomi adalah persetujuan tindakan kedokteran atau informed consent. ${ }^{1}$

Penyampaian informasi kepada pasien dalam persetujuan tindakan kedokteran harus mencakup semua hal yang penting untuk pengambilan keputusan mengenai tindakan. ${ }^{2-5}$ Persetujuan tindakan kedokteran atau informed consent dalam praktik kedokteran di Indonesia diatur dalam Undang-undang Nomor 29 Tahun 2009 tentang Praktik Kedokteran pada Paragraf 2 Pasal 45 Ayat 1 sampai 6, Undang-Undang Kesehatan Nomor 36 Tahun 2009 dan Peraturan Menteri Kesehatan (Permenkes) Nomor 290 Tahun 2008 tentang Persetujuan Tindakan Kedokteran. ${ }^{6,7}$ Lembar persetujuan tindakan kedokteran mampu melindungi dokter spesialis anestesi dalam melakukan tindakan anestesi secara hukum dan memberikan informasi sebanyak-banyaknya kepada pasien yang akan dilakukan tindakan mengenai risiko dan keuntungan tindakan anestesi. Dengan demikian, hal tersebut akan menguntungkan dan melindungi kedua belah pihak. ${ }^{6-9}$

Pemberian informasi mengenai prosedur anestesi umum diberikan melalui metode verbal atau lisan pada saat pasien berada di poli anestesi atau saat visite preoperatif di ruang rawat bersamaan dengan proses persetujuan tindakan kedokteran. Tujuan tindakan medis, prosedur, risiko, efek samping, alternatif tindakan, dan periode pemulihan pada kondisi tertentu perlu dipahami secara adekuat oleh pasien. Namun, kemampuan pasien yang berbeda-beda untuk menerima informasi, keengganan untuk bertanya, dan perbedaan kemampuan dalam mengetahui prosedur tindakan medis dapat menjadikan tujuan penyampaian informasi tidak tercapai. ${ }^{6,7}$

Persetujuan tindakan kedokteran baru diakui apabila pasien telah mendapatkan informasi yang jelas dari dokter tentang tindakan medis yang akan dilakukan. Setelah itu, pasien dapat menentukan sendiri keputusannnya sesuai dengan pilihannya (informed decision). ${ }^{6,7}$ Ia dapat memberikan pernyataan setuju dengan menandatangani lembar persetujuan tindakan kedokteran. Diharapkan, ditandatanganinya lembar persetujuan tindakan kedokteran menandakan bahwa pasien sudah benar-benar mengetahui segala informasi yang diberikan dan setuju untuk dilakukan tindakan medis terhadap dirinya beserta segala implikasinya. Pasien menyadari sepenuhnya segala risiko tindakan medik yang akan dilakukan dokter dan jika dalam tindakan medik itu terjadi sesuatu yang tidak diinginkan, pasien tidak akan mengadakan tuntutan apapun ke pengadilan di kemudian hari. ${ }^{6}$ Sebaliknya, apabila pasien menolak, ia dapat menandatangani lembar penolakan tindakan kedokteran. ${ }^{6,7}$ Berkaitan dengan hal tersebut, beberapa alat bantu telah digunakan dalam proses pemberian informasi untuk meningkatkan pengetahuan pasien, salah satunya dengan menggunakan presentasi multimedia. ${ }^{8,10}$

Terdapat beberapa penelitian yang mencoba mempelajari hubungan antara penggunaan presentasi video dan pengetahuan pasien terhadap tindakan medis secara umum dan tindakan anestesi secara khusus. Sebuah penelitian membandingkan tiga metode pemberian informasi preanestesi berbeda, yakni dengan metode verbal, kombinasi metode verbal, dan brosur serta metode verbal dan presentasi video. Penelitian tersebut menunjukkan kelompok dengan kombinasi metode verbal dan video menghasilkan persentase tertinggi untuk kategori kepuasan pasien dan pemahaman terhadap informasi yang diberikan, yakni berturut-turut sebanyak $98 \%$ dan $93 \% .^{11}$

Studi lain juga menunjukkan bahwa pasien dengan kombinasi metode verbal dan metode video memiliki persentase pengetahuan yang lebih baik mengenai proses anestesi, yakni sebanyak $47 \%$ berbanding 7,8\%, mengenai risiko tindakan anestesi sebanyak 
93\% berbanding 73,4\%, dan mengenai kesalahpahaman terkait anestesi sebanyak $50,8 \%$ berbanding $17,2 \% \cdot{ }^{12}$ Penelitian lainnya juga menunjukkan bahwa pengetahuan pasien pada kelompok dengan kombinasi metode verbal dan video lebih tinggi dibanding dengan kelompok metode verbal saja tanpa pengaruh yang signifikan mengenai waktu pemaparan video terhadap pasien baik sebelum maupun sesudah wawancara verbal. ${ }^{13}$

Rumah Sakit Dr Hasan Sadikin Bandung sebagai rumah sakit pusat rujukan di daerah Jawa Barat melakukan 14.149 operasi pada tahun 2015 dan 14.689 operasi pada tahun 2016. Makin bertambahnya jumlah operasi tiap tahunnya memberikan ruang untuk berbagai metode yang dapat membantu meningkatkan pemahaman pasien mengenai prosedur anestesi umum. Metode pemberian informasi saat persetujuan tindakan kedokteran yang dilakukan di Departemen Anestesi dan Terapi Intensif Rumah Sakit Dr Hasan Sadikin Bandung adalah metode verbal. Hingga saat ini, belum ada penelitian yang dilakukan untuk mengetahui pengaruh penggunaan alat bantu video terhadap pemahaman mengenai prosedur anestesi umum pada pasien yang akan menjalani operasi di Rumah Sakit Dr. Hasan Sadikin Bandung.

Penelitian ini bertujuan mengkaji perbandingan pemberian informasi verbal dengan presentasi video terhadap pengetahuan prosedur anestesi umum pada pasien yang akan menjalani operasi di Rumah Sakit Dr. Hasan Sadikin Bandung.

\section{Subjek dan Metode}

Penelitian ini merupakan penelitian eksperimental prospektif cross-sectional. Subjek penelitian adalah pasien yang dirawat di ruangan dan dijadwalkan untuk menjalani operasi elektif menggunakan anestesi umum, Kriteria inklusi adalah status fisik American Society of Anesthesiologists (ASA) kelas I yang berusia $>18$ tahun, pendidikan terakhir minimal setara SMA, dan mampu berkomunikasi menggunakan bahasa Indonesia. Kriteria eksklusi adalah pasien mengalami gangguan kognitif berdasar atas tes MMSE, gangguan pendengaran, gangguan penglihatani riwayat menjalani prosedur anestesi selama 6 bulan terakhir, dan pasien dengan rencana perawatan pascaoperasi di ruangan intensif.

Perhitungan jumlah sampel ditentukan menggunakan rumus perhitungan sampel untuk uji hipotesis antara dua populasi dari program sample size 2.0 dari Hosmer dan Lemeshow. Subjek penelitian ini terdiri atas 40 orang yang memenuhi kriteria inklusi dan tidak termasuk eksklusi. Pengambilan sampel pasien dilakukan secara consecutive sampling dan alokasi subjek ke dalam salah satu kelompok dilakukan dengan cara acak sederhana menggunakan amplop tertutup. Subjek penelitian diberikan perlakuan berupa pemberian informasi mengenai prosedur anestesi umum pada proses persetujuan tindakan kedokteran secara verbal pada kelompok pertama serta secara verbal dan video pada kelompok kedua.

Penelitian dilakukan di RSUP Dr. Hasan Sadikin, Jalan Pasteur 38 Bandung, dimulai sejak 6 Februari 2018 hingga 31 Maret 2018. Setelah mendapat persetujuan dari Komite Etik Penelitian Kesehatan Fakultas Kedokteran Universitas Padjadjarant RSUP Dr Hasan Sadikin Bandung, dilakukan penjelasan kepada subjek penelitian mengenai penelitian yang akan dilakukan. Pasien yang sesuai kriteria dan telah menandatangani formulir kesediaan mengikuti penelitian dijadikan sebagai subjek penelitian. Dilakukan randomisasi dengan metode acak sederhana menggunakan amplop tertutup dengan nomor 1-40 berisi kode perlakuan A atau B di dalamnya sehingga subjek terbagi menjadi dua kelompok perlakuan, yaitu kelompok metode verbal (kelompok V) dan kelompok metode multimedia (kelompok M).

Subjek penelitian pada kelompok V mendapatkan informasi mengenai tindakan anestesi secara verbal oleh residen anestesb pada saat visite preanestesi. Subjek penelitian pada kelompok $\mathrm{M}$ diberikan informasi mengenai tindakan anestesi secara verbal oleh residen anestesi dan melihat video presentasi 
mengenai tindakan anestesi di laptop yang disediakan oleh peneliti pada saat visite preanestesi. Kedua kelompok mendapatkan kesempatan tanya-jawab setelah pemberian informasi. Subjek penelitian kemudian diminta untuk mengisi kuesioner penilaian tingkat pengetahuan prosedur anestesi yang telah tervalidasi.

Data yang didapatkan kemudian diolah secara statistik. Untuk data numerik (usia pasien dan BMI), dilakukan uji normalitas dengan menggunakan Uji Sapiro-Wilk. Jika data berdistribusi normal, uji hipotesis untuk membandingkan karakteristik dua kelompok penelitian dilakukan dengan menggunakan uji $t$ tidak berpasangan. Uji Mann Whitney digunakan jika data tidak berdistribusi normal.

Perbandingan rerata sebelum dengan sesudah perlakuan dianalisis dengan menggunakan uji $\mathrm{t}$ berpasangan jika data berdistribusi normal atau uji Wilcoxon jika data tidak berdistribusi normal. Analisis statistik untuk data kategorik (jenis kelamin dan pekerjaan pasien) dilakukan dengan uji chi-square apabila syarat chi-square terpenuhi atau dengan uji Exact Fisher untuk tabel 2 x 2 dan Kolmogorov Smirnov untuk tabel selain $2 \times 2$ apabila syarat chi-square tidak terpenuhi. Data yang diperoleh diolah menggunakan program statistical product and service solutions (SPSS) versi 24.0 for windows.

\section{Hasil}

Karakteristik umum kedua kelompok penelitian berdasarkas usia, pendidikan dan skor MMSE tidak terdapat perbedaan yang signifikan ( $p>0.5$,; Tabel 1 )

Analisis statistik hasil kuesioner kategori proses anestesi antara kedua kelompok menunjukkan tidak terdapat perbedaan yang signifikan atau bermakna secara statistik. (nilai $\mathrm{p}>0.05$; Tabel 2).

Analisis statistik hasil kuesioner kategori risiko anestesi pada kedua kelompok penelitian menunjukkan perbedaan signifikan atau bermakna secara statistik hanya pada pertanyaan mengenai hubungan antara

Tabel Karakteristik Umum Subjek Penelitiian

\begin{tabular}{|c|c|c|c|}
\hline \multirow{3}{*}{ Variabel } & \multicolumn{2}{|c|}{ Kelompok } & \multirow{3}{*}{ Nilai p } \\
\hline & Verbal & Multimedia & \\
\hline & $\mathbf{n}=\mathbf{2 0}$ & $\mathrm{n}=\mathbf{2 0}$ & \\
\hline Usia (tahun) & & & 0,383 \\
\hline Mean \pm Std & $26,80 \pm 7,661$ & $27,55 \pm 5.679$ & \\
\hline Median & 25,00 & 27,00 & \\
\hline Range (min.-maks.) & $18,00-45,00$ & $20,00-40,00$ & \\
\hline Pendidikan & & & 1,000 \\
\hline SLTA & 11 & 11 & \\
\hline S1 & 9 & 9 & \\
\hline Skor MMSE & & & 0,565 \\
\hline Mean \pm Std & $28,85 \pm 1.268$ & $28,50 \pm 1.572$ & \\
\hline Median & 29,00 & 29,00 & \\
\hline Range (min.-maks.) & $26,00-30,00$ & $26,00-30,00$ & \\
\hline
\end{tabular}

Keterangan: untuk data numerik nilai p diuji dengan uji t tidak berpasangan apabila data berdsitribusi normal dengan alternatif Uji Mann Whitney apabila data tidak berdistribusi normal. Data kategorik nilai p dihitung berdasar atas uji chi-square dengan alternatif Uji Kolmogorov Smirnov dan Exact Fisher apabila syarat dari chi-square tidak terpenuhi. Nilai kemaknaan berdasar atas nilai $\mathrm{p}<0,05$. Tanda* menunjukkan nilai $\mathrm{p}<0,05$ artinya signifkan atau bermakna secara statistik 
Tabel 2 Perbandingan Hasil Kuesioner Kategori Proses Anestesi antara Kelompok Verbal dan Kelompok Multimedia

\begin{tabular}{|c|c|c|c|}
\hline \multirow{3}{*}{ Pertanyaan } & \multicolumn{2}{|c|}{ Kelompok } & \multirow{3}{*}{ Nilai p } \\
\hline & Verbal & Multimedia & \\
\hline & $n=20$ & $n=20$ & \\
\hline $\begin{array}{l}\text { Nyeri dan rasa mual dapat diatasi, pasien dapat meminta tolong dan } \\
\text { memberitahu perawat jika merasakan hal tersebut }\end{array}$ & & & 0,487 \\
\hline Betul & 20 & 18 & \\
\hline Salah & 0 & 2 & \\
\hline $\begin{array}{l}\text { Dokter anestesi akan mendampingi pasien selama pasien tertidur dan } \\
\text { menjalani operasi }\end{array}$ & & & 1,000 \\
\hline Betul & 20 & 20 & \\
\hline Salah & 0 & 0 & \\
\hline $\begin{array}{l}\text { Selang plastik akan dimasukkan ke dalam pembuluh darah dengan } \\
\text { menggunakan jarum untuk memasukkan obat-obatan dan cairan }\end{array}$ & & & 0,091 \\
\hline Betul & 14 & 19 & \\
\hline Salah & 6 & 1 & \\
\hline $\begin{array}{l}\text { Alat untuk memantau kondisi pasien akan dipasang sebelum pasien } \\
\text { ditidurkan }\end{array}$ & & & 0,487 \\
\hline Betul & 20 & 18 & \\
\hline Salah & 0 & 2 & \\
\hline $\begin{array}{l}\text { Pasien dapat meminta untuk bertemu dengan dokter anestesi setelah } \\
\text { operasi jika ada masalah yang dirasakan }\end{array}$ & & & 1,000 \\
\hline Betul & 18 & 19 & \\
\hline Salah & 2 & 1 & \\
\hline
\end{tabular}

kejadian menggigil dan alergi obat (nilai $\mathrm{p}<0,05$ ). Sementara itu, perbandingan hasil jawaban lainnya di kedua kelompok tidak menunjukkan perbedaan yang signifikan (nilai $\mathrm{p}>0,05$; Tabel 3).

Analisis statistik hasil kuesioner kategori kesalahpahaman anestesi pada kedua kelompok menunjukkan tidak terdapat perbedaan yang signifikan atau bermakna secara statistik ( $p>0,05$; Tabel 4).

Tabel 5 menunjukkan perbandingan pengetahuan mengenai ketiga aspek prosedur anestesi umum pada kelompok verbal dan multimedia. Pasien dianggap mengetahui mengenai salah satu aspek apabila dapat menjawab seluruh pertanyaan kategori tersebut dengan benar. Hasil jawaban kuesioner menunjukkan jumlah responden yang mengetahui aspek proses dan risiko anestesi pada kelompok multimedia lebih banyak dibanding dengan kelompok verbal, namun tidak terdapat perbedaan yang signifikan $(p>0,05)$. Dari hasil analisis data tidak didapatkan perbedaan pengetahuan yang signifikan $(p>0,05)$ untuk aspek proses dan risiko anestesi pada kelompok verbal dan multimedia. Jumlah responden yang mengetahui aspek kesalahpahaman pada kelompok multimedia lebih besar dibanding dengan kelompok verbal yang berbeda signifikan $(\mathrm{p}<0,05$; Tabel 5).

Tabel 6 menunjukkan empat orang subjek di kelompok multimedia yang memiliki pengetahuan mengenai prosedur anestesi 
Tabel 3 Perbandingan Hasil Kuesioner Kategori Risiko Anestesi antara Kelompok Verbal dan Kelompok Multimedia

\begin{tabular}{|c|c|c|c|}
\hline \multirow{3}{*}{ Pertanyaan } & \multicolumn{2}{|c|}{ Kelompok } & \multirow{3}{*}{ Nilai p } \\
\hline & Verbal & Multimedia & \\
\hline & $\mathbf{n}=\mathbf{2 0}$ & $n=20$ & \\
\hline $\begin{array}{l}\text { Pasien mungkin dapat merasakan selang di jalan napas saat } \\
\text { terbangun dari proses anestesi }\end{array}$ & & & 0,113 \\
\hline Betul & 8 & 13 & \\
\hline Salah & 12 & 7 & \\
\hline $\begin{array}{l}\text { Jika tubuh pasien menggigil setelah proses anestesi artinya pasien } \\
\text { tersebut alergi terhadap obat anestesi yang diberikan }\end{array}$ & & & $0,047^{* *}$ \\
\hline Betul & 10 & 16 & \\
\hline Salah & 10 & 4 & \\
\hline $\begin{array}{l}\text { Pasien dapat menggigil ataupun merasa kedinginan setelah proses } \\
\text { anestesi }\end{array}$ & & & 1,000 \\
\hline Betul & 20 & 20 & \\
\hline Salah & 0 & 0 & \\
\hline $\begin{array}{l}\text { Rasa nyeri dan mual-muntah dapat timbul setelah prosedur operasi } \\
\text { dan anestesi selesai }\end{array}$ & & & 1,000 \\
\hline Betul & 20 & 20 & \\
\hline Salah & 0 & 0 & \\
\hline $\begin{array}{l}\text { Saat menjalani prosedur anestesi dan operasi pasien dapat saja } \\
\text { mendengar dan merasakan segala sesuatu walaupun kejadiannya } \\
\text { sangat jarang }\end{array}$ & & & 0,102 \\
\hline Betul & 10 & 15 & \\
\hline Salah & 10 & 5 & \\
\hline $\begin{array}{l}\text { Pasien yang sehat dapat saja mengalami masalah saat prosedur } \\
\text { anestesi }\end{array}$ & & & 0,490 \\
\hline Betul & 13 & 15 & \\
\hline Salah & 7 & 5 & \\
\hline $\begin{array}{l}\text { Pasien dapat mengalami kerusakan gigi akibat pemasangan alat di } \\
\text { mulut saat prosedur anestesi }\end{array}$ & & & 1,000 \\
\hline Betul & 15 & 15 & \\
\hline Salah & 5 & 5 & \\
\hline Risiko terjadi kematian selama proses anestesi sangatlah rendah & & & 1,000 \\
\hline Betul & 19 & 20 & \\
\hline Salah & 1 & 0 & \\
\hline
\end{tabular}

Keterangan: untuk data kategorik nilai p dihitung berdasar atas uji chi-square dengan alternatif Uji Kolmogorov Smirnov dan Exact Fisher apabila syarat chi-square tidak terpenuhi. Nilai maknaan berdasar atas nilai $\mathrm{p}<0,05$. Tanda* menunjukkan nilai $\mathrm{p}<0,05$ artinya signifkan atau bermakna secara statistik

umum (mampu menjawab dengan benar seluruh 18 pertanyaan kuesioner), sedangkan tidak ada subjek di kelompok verbal yang memiliki pengetahuan mengenai proses, risiko, serta kesalahpahaman anestesi umum. Namun, perbedaan tersebut tidak bermakna secara statistik (nilai $\mathrm{p}>0,05$ ). 


\begin{tabular}{|c|c|c|c|}
\hline \multirow{3}{*}{ Pertanyaan } & \multicolumn{2}{|c|}{ Kelompok } & \multirow{3}{*}{ Nilai p } \\
\hline & $\begin{array}{c}\text { Edukasi } \\
\text { Verbal }\end{array}$ & $\begin{array}{c}\text { Edukasi } \\
\text { Multimedia }\end{array}$ & \\
\hline & $\mathbf{n}=\mathbf{2 0}$ & $\mathbf{n}=\mathbf{2 0}$ & \\
\hline $\begin{array}{l}\text { Dokter anestesi akan menidurkan pasien dan meninggalkannya } \\
\text { kepada dokter bedah untuk operasi }\end{array}$ & & & 0,127 \\
\hline Betul & 13 & 18 & \\
\hline Salah & 7 & 2 & \\
\hline $\begin{array}{l}\text { Banyak sekali pasien yang terbangun di tengah prosedur anestesi, } \\
\text { namun tidak dapat memberitahukan keadaannya kepada siapapun }\end{array}$ & & & 0,451 \\
\hline Betul & 14 & 17 & \\
\hline Salah & 6 & 3 & \\
\hline Anestesia diberikan berdasar atas instruksi dokter bedah & & & 0,206 \\
\hline Betul & 8 & 12 & \\
\hline Salah & 12 & 8 & \\
\hline $\begin{array}{l}\text { Jika ada cedera pada gigi hal itu disebabkan oleh ketidakhati-hatian } \\
\text { prosedur anestesi }\end{array}$ & & & 0,053 \\
\hline Betul & 9 & 15 & \\
\hline Salah & 11 & 5 & \\
\hline $\begin{array}{l}\text { Jika setelah operasi pasien merasa sakit atau tidak enak maka telah } \\
\text { terjadi sesuatu yang tidak seharusnya terjadi }\end{array}$ & & & 0,168 \\
\hline Betul & 12 & 16 & \\
\hline Salah & 8 & 4 & \\
\hline
\end{tabular}

Keterangan: untuk data kategorik nilai p dihitung berdasar atas uji chi-square dengan alternatif Uji Kolmogorov Smirnov dan Exact Fisher apabila syarat chi-square tidak terpenuhi. Nilai kemaknaan berdasar atas nilai p<0,05. Tanda* menunjukkan nilai $\mathrm{p}<0,05$ artinya signifkan atau bermakna secara statistik

\section{Pembahasan}

Karakteristik umum subjek pada kedua kelompok penelitian terhadap status ASA, jenis operasi, tingkat pendidikan, dan skor uji MMSE bersifat homogen sehingga layak untuk dibandingkan dan dilakukan uji statistik lebih lanjut. Penelitian ini menunjukkan 2 poin penting, poin pertama adalah jumlah jawaban kuesioner benar secara keseluruhan menunjukkan bahwa kelompok multimedia lebih banyak menjawab pertanyaan dengan benar dibanding dengan kelompok verbal (Tabel 2-Tabel 4). Poin kedua adalah pengetahuan prosedur anestesi umum (dinilai melalui kemampuan subjek untuk menjawab seluruh pertanyaan kuesioner dengan benar) yang secara keseluruhan juga menunjukkan bahwa lebih banyak subjek di kelompok multimediayangmengetahuiproseduranestesi umum dibanding kelompok verbal (Tabel 5 dan 6), walaupun secara statistik perbedaan tersebut tidak bermakna. Hasil tersebut kemungkinan disebabkan oleh beberapa hal. Teori multimedia active processing assumption menyatakan bahwa seseorang akan menyusun struktur pengetahuan dari hal-hal yang relevan terhadap informasi yang ingin disampaikan. Video sebagai salah satu bentuk multimedia dapat dirancang sedemikian rupa untuk memuat hal-hal yang relevan dengan informasi. Namun, proses penyampaian informasi dapat kurang optimal apabila terdapat elemen seperti animasi, musik, 
Tabel 5 Perbandingan Pengetahuan Mengenai Aspek Proses, Risiko, dan Kesalahpahaman Anestesi Umum antara Kelompok Verbal dan Kelompok Multimedia

\begin{tabular}{|c|c|c|c|}
\hline \multirow{3}{*}{ Pengetahuan Berbagai Aspek Prosedur Anestesi Umum } & \multicolumn{2}{|c|}{ Kelompok } & \multirow{3}{*}{ Nilai p } \\
\hline & Verbal & Multimedia & \\
\hline & $\mathbf{n}=\mathbf{2 0}$ & $\mathrm{n}=\mathbf{2 0}$ & \\
\hline Pengetahuan proses & & & 0,490 \\
\hline Tahu & 13 & 15 & \\
\hline Tidak tahu & 7 & 5 & \\
\hline Pengetahuan risiko & & & 0,144 \\
\hline Tahu & 3 & 7 & \\
\hline Tidak tahu & 17 & 13 & \\
\hline Pengetahuan kesalahpahaman & & & 0,022 \\
\hline Tahu & 4 & 11 & \\
\hline Tidak tahu & 16 & 9 & \\
\hline
\end{tabular}

Keterangan: untuk data kategorik nilai p dihitung berdasar atas uji chi-square dengan alternatif Uji Kolmogorov Smirnov dan Exact Fisher apabila syarat chi-square tidak terpenuhi. Nilai kemaknaan berdasar atas nilai $\mathrm{p}<0,05$. Tanda* menunjukkan nilai $\mathrm{p}<0,05$ artinya signifkan atau bermakna secara statistik

narasi, maupun gambar yang tidak berkaitan dengan informasi karena justru menambah beban kerja memori dalam menyeleksi gambar maupun kata-kata yang saling terkait dan menghambat proses pembentukan struktur kognitif. Desain video yang lebih baik dan fokus kepada informasi yang akan disampaikan mungkin akan dapat mengoptimalkan proses penyampaian informasi. ${ }^{14,15}$

Sebuah penelitian tahun 2007 menyatakan bahwa kendali dari pihak penerima informasi merupakan faktor yang dapat menentukan keberhasilan proses pembelajaran dan penerimaan informasi yang menggunakan media animasi. Penelitian tersebut menyatakan bahwa proses pembelajaran menggunakan multimedia berpusat kepada penerima informasi dan bukan teknologinya sehingga keterlibatan penerima informasi untuk menghentikan serta memulai animasi berdasar atas keinginan sendiri dan bukan hanya menonton selintas akan meningkatkan efektivitas animasi tersebut dalam proses pembelajaran. Tata cara pada penelitian ini yang tidak memungkinkan subjek untuk terlibat dalam pemutaran videonya dapat menjadi satu faktor yang berpengaruh terhadap hasil penelitian ini. ${ }^{14,15}$

Teori cognitive load menyatakan bahwa terdapat 3 tipe proses kerja kognitif, yakni

Tabel 6 Perbandingan Pengetahuan Prosedur Anestesi Umum antara Kelompok Video dan Verbal

\begin{tabular}{|c|c|c|c|}
\hline \multirow{3}{*}{ Pengetahuan Prosedur Anestesi Umum } & \multicolumn{2}{|c|}{ Kelompok } & \multirow{3}{*}{ Nilai p } \\
\hline & Verbal & Multimedia & \\
\hline & $\mathbf{n}=20$ & $\mathrm{n}=20$ & \\
\hline Betul & 0 & 4 & 0,106 \\
\hline Salah & 20 & 16 & \\
\hline
\end{tabular}

Keterangan: untuk data kategorik nilai p dihitung berdasar atas uji chi-square dengan alternatif Uji Kolmogorov Smirnov dan Exact Fisher apabila syarat chi-square tidak terpenuhi. Nilai kemaknaan berdasar atas nilai $\mathrm{p}<0,05$. Tanda* menunjukkan nilai $\mathrm{p}<0,05$ artinya signifkan atau bermakna secara statistik 
intrinsik, extraneous, dan germane. Proses intrinsik merupakan proses mempelajari materi inti atau informasi yang disampaikan. Proses germane merupakan proses mengorganisasi dan mengintegrasikan informasi yang baru saja didapat menjadi suatu struktur pengetahuan baru. Proses extraneous merupakan proses yang dapat menghambat transfer informasi seperti melakukan aktivitas yang dapat membuat konsentrasi penerima informasi terbagi. Hal tersebut disebut juga dengan split-attention focus. Proses extraneous inilah yang dapat menjadi penyebab tidak optimalnya transfer informasi saat penelitian ini karena pasien tidak ditempatkan di ruangan khusus untuk menonton video ataupun menerima informasi verbal tanpa interupsi, tetapi masih dapat terganggu oleh telepon genggam, interaksi dengan keluarga yang mendampingi, atau bahkan dengan perawat maupun dokter lain yang mendatangi pasien saat proses pemberian informasi berlangsung. ${ }^{14,15}$

Penyebab selanjutnya yang dapat membuat tidak terbuktinya hipotesis adalah kuesioner yang mungkin kurang dapat dipahami oleh responden. Penelitian sebelumnya di Australia oleh Done dkk. menggunakan kuesioner dengan pertanyaan yang sama memberikan hasil sebanyak 15 orang dari kelompok video dan 2 orang dari kelompok verbal dapat menjawab seluruh soal dengan benar. Namun, pada penelitian ini hanya terdapat 4 orang dari kelompok video yang dapat menjawab seluruh soal dengan benar dan tidak ada sama sekali dari kelompok verbal. Video yang digunakan sama-sama memuat seluruh informasi yang ditanyakan pada kuesioner. Hal ini menunjukkan kemungkinan bahwa pertanyaan kuesioner yang diterjemahkan ke dalam bahasa Indonesia mungkin sulit dimengerti oleh subjek penelitian ini. Hal tersebut dapat disebabkan oleh perbedaan budaya maupun tingkat pendidikan yang antara kedua negara. ${ }^{11,12}$ Namun, hasil tersebut bukanlah berarti bahwa metode video tidak memiliki manfaat lebih dibanding dengan metode verbal dalam proses pemberian informasi kepada pasien yang akan menjalani prosedur anestesi umum karena berdasar atas literatur metode multimedia masih memiliki keunggulan dibanding dengan metode verbal.

\section{Simpulan}

Pada penelitian ini tidak terdapat perbedaan antara pemberian informasi melalui metode verbal dan presentasi video terhadap pengetahuan pasien mengenai prosedur anestesi umum. Dibutuhkan penelitian lebih lanjut menggunakan video dengan konten yang lebih baik, pengkondisian subjek penelitian yang bebas dari gangguan selama proses penyampaian informasi, dan kuesioner yang dirancang dengan lebih baik untuk dapat mengetahui lebih baik lagi manfaat video sebagai alat bantu penyampaian informasi prosedur anestesi umum kepada pasien yang akan menjalani operasi. Tingkat kepuasan pasien terhadap proses pemberian informasi serta pengaruh pemberian informasi yang jelas pada tingkat kecemasan pasien terhadap tindakan yang akan dijalani dapat dijadikan bahan untuk penelitian selanjutnya terkait proses persetujuan tindakan kedokteran secara umum dan persetujuan tindakan anestesi secara khusus.

\section{Daftar Pustaka}

1. Osman H. History and development of the doctrine of informed consent. Int Electron J Health Educ. 2001;4(1):41-7.

2. MacKenzie $R$, Green D. Nuances of informed consent: the paradigm of regional anesthesia. HSS J. 2007;3(1):115-8.

3. White C, Rosoff AJ, LeBLang TR. Informed consent to medical and surgical treatment. Dalam: Sanbar S, penyunting. Legal medicine. Edisi ke-7. Philadhelpia: Mosby; 2006. hlm. 337-46.

4. King JS, Moulton B. Rethinking informed consent: the case for shared medical decision making. Am J Law Med. 2006; 32(1):429-501.

5. Murray B. Informed consent: what must a physician disclose to a patient? Virtual Mentor. 2012;14(7):563-6. 
6. Pakendek A. Informed consent dalam pelayanan kesehatan. Al-Ihkam J Hukum Pranata Sosial. 2010;5(2): 309-18.

7. Kristanti YM, Sri A. Pelaksanaan persetujuan tindakan medis antara dokter dengan pasien peserta jaminan kesehatan masyarakat (Jamkesmas) di RSUD Pandan Arang Kabupaten Boyolali. Privat Law. 2013;3(1):50-8.

8. Tait AR. Digital multimedia: a new approach for informed consent. JAMA. 2015;313(5):463-4.

9. Jlala HA, French JL, Foxal GL, Hardman JG, Bedforth NM. Effect of preoperative multimedia information on perioperative anxiety in patients undergoing procedures under regional anesthesia. Br J Anaesth. 2010;104(3):369-74.

10. Spencer S, Stoner M, Kelleher K, Cohen D. Using a multimedia presentation to enhance informed consent in a pediatric emergency departement. Pediatr Emerg Care. 2015;31(8);572-6.

11. Snyder-Ramos S, Seintsch H, Bottiger
B, Motsch J, Martin E, Bauer M. Patient satisfaction and information gain after the preanesthetic visit: a comparison of faceto-face interview, brochure, and video. Anesth Analg. 2005;100:1753-8.

12. Done ML, Lee A. The use of a video to convey preanesthetic information to patients undergoing ambulatory surgery. Anesth Analg. 1998;87:531-6.

13. Salzwedel C, Petersen C, Blanc I, Koch U, Goetz AE, Schuster M. The effect of detailed, video-assisted anesthesia risk education on patient anxiety and the duration of the preanesthetic interview: a randomized controlled trial. Anesth Analg. 2008;106(1):202-9.

14. Samaras H, Giouvanakis T, Bousiou D, Tarabanis K. Towards a new generation of multimedia learning research. AACE J. 2006;14(1):3-30.

15. Sorden SD. The cognitive theory of multimedia learning. Handbook of educational theories, 1. 2012;(2012):122. 